\title{
Penicillium and Talaromyces Communities of Sugarcane Soils (Saccharum officinarum L.): Ecological and Phylogenetic Aspects
}

\author{
Sérgio Murilo Sousa Ramos ${ }^{1}$, Roberta $\mathrm{Cruz}^{2}$, Renan do Nascimento Barbosa ${ }^{1}$, Alexandre Reis Machado ${ }^{1}$, \\ Antônio Félix da Costa ${ }^{3}$, Cristina Maria de Souza Motta ${ }^{1} \&$ Neiva Tinti de Oliveira ${ }^{1}$ \\ ${ }^{1}$ Mycology Department, Federal University of Pernambuco, Recife, Pernambuco State, Brazil \\ ${ }^{2}$ Academic Unit of Garanhuns, Federal Rural University of Pernambuco, Garanhuns, Pernambuco, Brazil \\ ${ }^{3}$ Agronomic Institute of Pernambuco, Recife, Pernambuco State, Brazil \\ Correspondence: Sérgio Murilo Sousa Ramos, Mycology Department, Federal University of Pernambuco, Av. \\ Professor Nelson Chaves, s/n, 50670-420, Cidade Universitária, Recife, Pernambuco State, Brazil. Tel: \\ 55-81-2126-8948. Fax: 55-81-2126-8480. E-mail: sergio.ramos@barreiros.ifpe.edu.br
}

Received: January 2, 2018

doi:10.5539/jas.v10n4p335

\author{
Accepted: February 11, $2018 \quad$ Online Published: March 15, 2018 \\ URL: https://doi.org/10.5539/jas.v10n4p335
}

\begin{abstract}
Penicillium and Talaromyces are fungal genera with high ecological and biotechnological importance. However, studies on exploration and ecology of these fungi in soils are scarce. The objectives of this study were to evaluate the species diversity of these genera in soils of sugarcane and fallow. Identification of the isolates was performed by morphological examination and partial sequencing of $\beta$-tubulin. For ecological analyses, indexes were applied and principal component analysis (PCA) was performed. A total of 1,344 isolates were obtained: 1,108 of Penicillium (13 species) and 236 of Talaromyces (three species). Seven isolates did not cluster with any known species. The diversity and equitability indexes were similarly high for the two areas analyzed. Penicillium wotroi and Talaromyces murroi were more abundant. The PCA was significant and showed 2 groups: fallow and cultivated. Soils of sugarcane cultivation present distinct communities of Penicillium and Talaromyces species that are rare and/or not yet described by science.
\end{abstract}

Keywords: diversity, Eurotiomycetes, PCA, Trichocomaceae

\section{Introduction}

Penicillium and Talaromyces are genera of filamentous fungi of high environmental and biotechnological relevance (Pitt, 1991; Houbraken \& Samson, 2011; Taniwaki et al., 2015). Due to their low nutritional requirements and large enzymatic apparatus, they have been frequently isolated in soils of the most varied tropical ecosystems (e.g., Cruz et al., 2013; Barbosa et al., 2015), actively participating in biogeochemical cycles (Visagie et al., 2014). The taxonomy of these genera has been constantly reviewed and new approaches to identification, including molecular biology techniques, have been used in several studies (Romero et al., 2016; Visagie et al., 2016; Wang et al., 2017); however, studies on prospecting and ecology of these genera in tropical soils are still scarce, including in Brazil, which is recognized for harboring an important component of the planet's biodiversity (Cruz et al., 2013).

In northeastern Brazil, especially in the coastal zone of Pernambuco, areas of the Atlantic Forest biome were devastated to give rise to the cultivation of sugarcane (Saccharum officinarum L.) (Moraes et al., 2016), however, studies on the fungal communities present in its rhizosphere are scarce. This culture was introduced to the country in the year 1532, taking a place of great prominence in its economy. Currently, Brazil is the largest producer of sugarcane in the world, followed by India and China. According to data from the Compahia Nacional de Abastecimento (CONAB, 2017), the 2016/2017 harvest was 657.18 million tons. The northeastern region produced 45.46 million tons, with Pernambuco being the second largest producer state in the region (CONAB, 2017). Due to the favorable climatic and soil conditions, the coastal zone of the state of Pernambuco is ideal for the cultivation of sugarcane (Pereira \& Alves, 2007).

In the top layer of the soil, specifically at a depth of $1-30 \mathrm{~cm}$, the greatest microbial activity occurs, mainly due to the high level of oxygenation (Araújo \& Monteiro, 2007). In this layer, fungi are found in communities ranging from $10^{4}$ to $10^{6}$ colony forming units per gram of soil (Blackwell, 2011), with emphasis on the 
communities of Penicillium and Talaromyces. Therefore, any mechanical and/or physicochemical alteration of the soil directly impacts these communities and may alter both their abundance and their diversity (Araújo, 2007; Alves et al., 2011).

In the latter, the practice of application of vinasse occurs in the soil. Vinasse is the most important residue generated by the sugar and alcohol industry, mainly due to the large volume produced. From the production of 1 $\mathrm{L}$ of alcohol, approximately $13 \mathrm{~L}$ of vinasse are generated. This residue contains a high concentration of nutrients, mainly potassium $(\mathrm{K})$, and of organic matter, evidencing, therefore, a high polluting potential. The most viable alternative to waste disposal is the application of vinasse to soils cultivated with sugarcane (Barros, 2010). The effects of soil vinasse addition on soil $\mathrm{pH}$ can be emphasized, as well as the macronutrient content of the soil (Glória \& Orlando Filho, 1983; Silva et al., 2007). This practice has been associated with an increase in soil fertility, due to the nutrient supply and the increase in organic matter caused by the residue. In fact, in the present study there was a slight increase in both the $\mathrm{pH}$ values and the availability of potassium, carbon, and organic matter in the fallow soil samples. In addition, the greater nutrient supply in this soil can justify both the high diversity of species, especially Penicillium, and the greater abundance, since, according to Glória and Orlando Filho (1983), vinasse may be the cause of a population increase in soil microorganisms.

Considering the above, the objectives of this study were to assess the diversity of Penicillium and Talaromyces in soils under sugarcane (Saccharum officinarum L.) cultivation and fallow (without cane) from an area located in the municipality of Sirinhaém (Atlantic Forest area), Pernambuco, Brazil and to evaluate its relationship with the physicochemical properties of soil.

\section{Material and Methods}

\subsection{Study Area}

The study was carried out in an agricultural area of the Trapiche mill $\left(8^{\circ} 35^{\prime} 21^{\prime \prime} \mathrm{S}, 35^{\circ} 6^{\prime} 55^{\prime \prime} \mathrm{W}\right)$, located in the municipality of Sirinhaém, on the south coast of Pernambuco, in a soil classified as dystrophic yellow latosol/very clayey (Saldanha et al., 2007). The experiment was developed in 12 fields, six in fallow area and six in cultivated area. According to the Köppen system, the Ams' climate, a rainy monsoon tropical climate with a dry summer, with an average annual rainfall of approximately $2.295 .5 \mathrm{~mm}$ predominates in the area (Koffler et al., 1986). It is a common practice to apply pure vinasse to the soils when they are in fallow (rest) to increase their fertility.

\subsection{Collection and Isolation of Species of Penicillium and Talaromyces Present in Sugarcane Cultivation Soil in the Municipality of Sirinhaem, Pernambuco, Brazil}

Six soil samples were taken from cultivated and fallow areas (no planted cane). The samples were collected in November and December 2014 and January, April, May and June 2015. For each area, the soil samples were collected in three transects of $4 \times 25 \mathrm{~m}$, at a depth of $0-20 \mathrm{~cm}$, and a total of three samples per area were studied. Immediately after sampling, they were stored in sterile plastic bags, kept at room temperature $\left( \pm 25^{\circ} \mathrm{C}\right)$, and transported to the Laboratory of Phytopathogenic Fungi and Biocontrolers of the Mycology Department of the Biosciences Center of the Universidade Federal de Pernambuco (UFPE) for further analysis.

\subsection{Analysis of Physical-Chemical Characteristics of Soil Samples}

The analysis of $\mathrm{pH}$, available contents of $\mathrm{Al}, \mathrm{Ca}, \mathrm{Mg}, \mathrm{K}, \mathrm{Na}, \mathrm{P}$, active acidity $(\mathrm{H}), \mathrm{C}$, and organic matter were conducted by the Instituto de Agropecuária de Pernambuco (IPA), according to methodology described in the Manual of Methods of Soil Analysis of the Empresa Brasileira de Pesquisa Agropecuária (EMBRAPA, 2009). The $\mathrm{pH}$ was obtained from the mixture of soil in water at the ratio of $1: 2.5$. The $\mathrm{Al}^{3+}, \mathrm{Ca}^{2+}$, and $\mathrm{Mg}^{2+}$ contents of the soil were extracted using a of $1 \mathrm{~mol} \mathrm{~L}^{-1} \mathrm{KCl}$ solution in the proportion 1:10 and quantified by titration. Potassium, $\mathrm{Na}$, and $\mathrm{P}$ were extracted using Mehlich-1 solution at the ratio of 1:1 (soil:solution). Potassium and $\mathrm{Na}$ contents were determined by flame photometry, and the $\mathrm{P}$ content was determined by a spectrophotometer at $725 \mathrm{~nm}$. The potential acidity $(\mathrm{H}+\mathrm{Al})$ was extracted with calcium acetate and quantified by titration. All analyses were performed in triplicate.

\subsection{Isolation and Purification of Penicillium and Talaromyces Cultures}

Isolation of the fungal cultures under study was performed according to the suspension method (serial dilution) proposed by Clark (1965). All 36 composite soil samples were suspended in sterile distilled water and successive dilutions were performed. Suspensions were obtained at a concentration of 1:1000 $\mathrm{g} \mathrm{mL}^{-1}$. Each of the composite soil-in-water suspension samples was inoculated into five different Sabouraud agar-containing petri dishes $(90 \times$ $15 \mathrm{~mm}$ ) supplemented with $50 \mathrm{mg} \mathrm{L}^{-1}$ of chloramphenicol (SA-C), and five Petri dishes containing Dicloran agar 
supplemented with rose Bengal with $50 \mathrm{mg} \mathrm{L}^{-1}$ of chloramphenicol (DRB-C). In total, 360 Petri dishes were inoculated and maintained at $28^{\circ} \mathrm{C}\left( \pm 2{ }^{\circ} \mathrm{C}\right)$ for $72 \mathrm{~h}$ (Cruz et al., 2013).

For isolate purification, fragments of fungal colonies were transferred to Petri dishes containing SA-C medium. After confirmation of purity, fungus cultures were maintained in malt extract agar (MEA, Oxoid) at $25{ }^{\circ} \mathrm{C}$ $\left( \pm 2{ }^{\circ} \mathrm{C}\right)$.

\subsection{Morphological Analysis}

For morphological analysis, the isolates were cultured equidistant points in creatine sucrose agar (CREA) medium, Czapek yeast extract agar (CYA), CYA supplemented with $5 \% \mathrm{NaCl}$ (CYAS), dicloran 18\% glycerol agar (DG18), MEA, oatmeal agar, and yeast extract sucrose agar (YES) and maintained in BOD at $25^{\circ} \mathrm{C}$ for 7 days. Culture media were prepared as described in Samson et al. (2010). Macroscopic characteristics (color, appearance, and diameter of the colonies) were observed (Pitt, 1991; Raper \& Thom, 1949; Samson et al., 2010). Microscopic observations of the asexual stage were observed in colonies grown in MEA, and the presence of the sexual stage in colonies grown in CYA, MEA, and AO. All slides were prepared with lactic acid $(60 \%)$ and $96 \%$ ethanol. Finally, a representative of each species was added to the Catalogue of Micoteca URM Culture Collection (WDCM604) (Tabela 2).

\subsection{Molecular Identification of Species}

For molecular analysis, isolates of Penicillium and Talaromyces that showed morphological divergence and inconclusive identification (47 isolates) were cultivated in MEA at $25{ }^{\circ} \mathrm{C}$ for 7 days for subsequent molecular identification. Extraction of genomic DNA was performed using the UltraClean Microbial DNA isolation kit (Mo Bio Laboratories, Carlsbad, CA) following the manufacturer's recommendations. The $\beta$-tubulin (BenA) gene region was amplified for all isolates using the Bt2a and Bt2b primers (Glass \& Donaldson, 1995) and the PCR conditions described by Visagie et al. (2014). PCR products were purified using the Exosap illustrative enzyme ExoProStar TM 1-Step (GE Healthcare Life Sciences) and sequenced on the LABCEN/CCB sequencing platform at the UFPE (Recife, Brazil). The electropherograms were analyzed using the software BioEdit (Hall, 2014) from which the consensus nucleotide sequences were obtained. All sequences obtained were deposited in GenBank (http://www.ncbi.nlm.nih.gov) (MG452803 to MG452849).

For phylogenetic analysis, the obtained BenA sequences were added to a set of reference sequences or, where possible, the Penicillium and Talaromyces species types, obtained from GenBank and aligned in ClustalW (Higgins et al., 1994) implemented in MEGA v. 7 (Kumar et al., 2015). The generated alignments were deposited in TreeBASE (http://www.treebase.org/) under the access number S21877.

Phylogenetic analyses were performed by Bayesian inference in the Mr. Bayes v.3.2.2 program (Ronquist \& Huelsenbeck, 2003) implemented in the CIPRES Science Gateway online platform (Miller et al., 2010). Nucleotide substitution models were searched through Mr. MODELTEST 2.3 (Posada \& Buckley, 2004), estimated separately for each alignment, and selected according to the Akaike Information Criterion. The GTR + $\mathrm{I}+\mathrm{G}$ model were selected for Penicillium and HKY $+\mathrm{I}+\mathrm{G}$ for Talaromyces. Four MCMC chains were simultaneously initiated up to 10 million generations, and one tree was sampled every 1000 generations. Of the 10,000 sampled trees, $25 \%$ were discarded from the analysis and probability values (Rannala and Yang, 1996) were subsequently determined from the consensus tree through the remaining 7,500 trees. The resulting trees were viewed and edited in the FigTree software (Rambaut, 2009) and then exported to graphics programs.

\subsection{Ecological Analysis of Penicillium and Talaromyces Communities}

Statistical analysis of the species diversity of the genera present in soils of sugarcane cultivation areas was carried out using the Shannon index. Equitability was quantified by using the Pielou index (Pinto-Coelho, 2002). Abundance was calculated according to Magurran (1988), and relative dominance was established by the equation $\mathrm{DA}=\mathrm{NA} / \mathrm{NA}+\mathrm{NB}+\mathrm{NC} \ldots \mathrm{NN} \times 100$, where DA stands for species dominance, and NA + NB + $\mathrm{NC} \ldots \mathrm{NN}$ means the number of individuals of species $\mathrm{A}, \mathrm{B}, \mathrm{C} \ldots \mathrm{N}$. The species with percentages greater than $50 \%$ were considered dominant (Magurran, 1988). The species frequency during the study was calculated by the equation $\mathrm{FA}=\mathrm{PA} / \mathrm{P} \times 100$, where $\mathrm{F}$ is the frequency of species $\mathrm{A}$; PA is the number of samples where species $\mathrm{A}$ is present, and $\mathrm{P}$ is the total number of samples. According to Magurran (1988), $\mathrm{F} \geq 50 \%=$ constant species, $10 \%<\mathrm{F} \leq 49 \%=$ common species, and $\mathrm{F} \leq 10 \%=$ rare species. The similarity-dissimilarity of Penicillium species as well as that of Talaromyces between the cultivated and fallow areas were tested based on the BrayCurtis distance which ranged from 0 (similarity) to 1 (dissimilarity), using the density matrix of the species (Pinto-Coelho, 2002). The analysis was performed between collections. The method of dendrogram binding was that of the Weight Pair Group Method with Arithmetic Mean (WPGMA) (Rohlf \& Fisher, 1968). These 
calculations were performed using the Numerical Taxonomy and Multivariate Analysis System (NTSYS) software from Exeter Software, USA (Rohlf, 1993).

\section{Results}

\subsection{Analysis of Physical-Chemical Characteristics of Soil Samples}

The values obtained for the physical-chemical analysis of soil samples are presented in Table 1. In the fallow area, higher values of $\mathrm{pH}, \mathrm{C}, \mathrm{P}, \mathrm{K}$, and organic matter contents and higher temperatures were observed, when compared with the cultivated area.

Table 1. Abiotic factors analysis of soil samples from area cultivated with sugarcane (Saccharum officinarum L.) and soil from fallow area, from a plant located in the municipality of Sirinhaém, Pernambuco, Brazil.

\begin{tabular}{|c|c|c|c|c|c|c|c|c|c|c|c|c|}
\hline \multirow{2}{*}{ Fcators } & \multicolumn{6}{|c|}{ Cultivated Area } & \multicolumn{6}{|c|}{ Area in fallow } \\
\hline & C1 & $\mathrm{C2}$ & $\mathbf{C 3}$ & $\mathrm{C4}$ & C5 & C6 & C1 & $\mathrm{C2}$ & $\mathbf{C 3}$ & $\mathrm{C4}$ & C5 & C6 \\
\hline Temperature & 28 & 29 & 30 & 30 & 29 & 30 & 30 & 30 & 32 & 32 & 34 & 33 \\
\hline pH & 5.4 & 5.3 & 5.2 & 5.3 & 5.2 & 5.2 & 5.8 & 5.8 & 5.6 & 5.7 & 5.6 & 5.6 \\
\hline$P\left(\mathrm{mg} \mathrm{kg}^{-1}\right)$ & 13.0 & 15.0 & 17.0 & 27.0 & 28.0 & 30.0 & 68.0 & 3.0 & 23.0 & 65.0 & 60.0 & 10.0 \\
\hline Al (cmolc kg $\left.{ }^{-1}\right)$ & 0.15 & 0.20 & 0.25 & 0.15 & 0.23 & 0.15 & 0.0 & 0.0 & 0.0 & 0.05 & 0.0 & 0.05 \\
\hline $\mathrm{Na}\left(\mathrm{cmolc} \mathrm{kg}^{-1}\right)$ & 0.50 & 0.25 & 0.20 & 0.18 & 0.20 & 0.23 & 0.04 & 0.04 & 0.08 & 0.03 & 0.04 & 0.05 \\
\hline $\mathrm{K}\left(\mathrm{cmolc} \mathrm{kg}^{-1}\right)$ & 0.14 & 0.12 & 0.14 & 0.13 & 0.14 & 0.14 & 0.20 & 0.14 & 0.17 & 0.18 & 0.17 & 0.20 \\
\hline Ca $\left(\mathrm{cmolc} \mathrm{kg}^{-1}\right)$ & 2.0 & 2.70 & 2.80 & 2.60 & 2.40 & 2.00 & 2.30 & 3.40 & 0.75 & 0.83 & 0.90 & 3.00 \\
\hline $\operatorname{Mg}\left(\mathrm{cmolc} \mathrm{dm} \mathrm{dm}^{-3}\right)$ & 1.10 & 1.30 & 1.10 & 1.10 & 1.10 & 1.30 & 0.90 & 0.80 & 0.75 & 0.90 & 0.80 & 0.70 \\
\hline H $\left(\right.$ cmolc dm $\left.{ }^{-3}\right)$ & 4.71 & 5.11 & 4.10 & 5.20 & 4.20 & 5.30 & 4.90 & 2.25 & 4.80 & 4.70 & 2.45 & 4.60 \\
\hline Organic Matter (\%) & 2.17 & 2.27 & 2.72 & 2.17 & 2.27 & 2.60 & 2.29 & 2.44 & 2.58 & 2.30 & 2.45 & 2.60 \\
\hline Carbon (\%) & 1.26 & 1.32 & 1.58 & 1.20 & 1.27 & 1.30 & 1.33 & 1.42 & 1.50 & 1.37 & 1.40 & 1.53 \\
\hline
\end{tabular}

Note. $\mathrm{C} 1=$ collection $1 ; \mathrm{C} 2=$ collection $2 ; \mathrm{C} 3=$ collection $3 ; \mathrm{C} 4=$ collection $4 ; \mathrm{C} 5=$ collection $5 ; \mathrm{C} 6=$ collection 6 .

\subsection{Species Identification}

Were obtained 1,344 CFUs, of which 674 were from the cultivated area, and 670 were from the fallow area. For the species identification, 47 BenA sequences of Penicillium and Talaromyces were obtained and presented aproximatelly 350 to $500 \mathrm{bp}$ in length, from which 16 species were identified, 13 and 3 belonging to the genera Penicillium and Talaromyces, respectively (Table 2). Eleven species (nine of Penicillium and two of Talaromyces) occurred in the cultivated area, seven of which were exclusive to the area (Penicillium javanicum, P. limosum, Penicillium sp. 1, Penicillium sp. 3, Penicillium sp. 6, Talaromyces muroii, and Talaromyces sp. 1). In the fallow area, nine species were found (eight from Penicillium and one from Talaromyces), six of which were restricted to the area (Penicillium paxilii, P. rubens, P. sanshaense, Penicillium sp. 5, and Talaromyces verruculosus) (Table 2 ). Of the 47 isolates analyzed, seven isolates (seven clades) did not cluster with any known species and are treated here as Penicillium sp. and Talaromyces sp. (Table 2, Figures 1 and 2). These putative new species are in the process of taxonomic description and will be presented in a later work. 
Table 2. Number of Colony Forming Units (CFU) of Penicillium and Talaromyces species by collection. (Atlântic Forest), from a sugar mill located in the municipality of Sirinhaém, Pernambuco, Brazil and Relative Dominance, according to Magurran (1988).

\begin{tabular}{|c|c|c|c|c|c|c|c|c|c|c|c|c|c|c|c|c|c|c|c|}
\hline \multirow[b]{2}{*}{ Specie } & \multicolumn{9}{|c|}{ Cultivated Area } & \multicolumn{9}{|c|}{ Fallow Area } & \multirow{2}{*}{$\begin{array}{l}\text { GRAND } \\
\text { TOTAL }\end{array}$} \\
\hline & $\mathrm{C} 1$ & $\mathrm{C} 2$ & $\mathrm{C3}$ & $\mathrm{C} 4$ & C5 & C6 & $\mathbf{T}$ & $\begin{array}{l}\text { RD } \\
(\%)\end{array}$ & $\begin{array}{l}\text { RF } \\
(\%)\end{array}$ & C1 & $\mathrm{C2}$ & $\mathbf{C 3}$ & $\mathrm{C} 4$ & C5 & C6 & $\mathbf{T}$ & $\begin{array}{l}\text { RD } \\
(\%)\end{array}$ & $\begin{array}{l}\text { RF } \\
(\%)\end{array}$ & \\
\hline Penicillium citrinum Thom & 10 & 07 & 05 & 12 & 08 & 08 & 50 & 7.4 & 100 & 15 & 20 & 21 & 15 & 05 & 12 & 88 & 13.1 & 100 & 138 \\
\hline P. javanicum J.F.H. Beyma & 10 & 05 & 03 & 13 & 04 & 03 & 38 & 5.6 & 100 & 0 & 0 & 0 & 0 & 0 & 0 & $\mathbf{0}$ & 0.0 & 0.0 & 38 \\
\hline P. limosum $\mathrm{S}$. Ueda & 13 & 17 & 25 & 22 & 25 & 27 & 129 & 19.1 & 100 & 0 & 0 & 0 & 0 & 0 & 0 & $\mathbf{0}$ & 0.0 & 0.0 & 129 \\
\hline P. paxilli Bainier & 0 & 0 & 0 & 0 & 0 & 0 & 0 & 0.0 & 0.0 & 13 & 15 & 15 & 6 & 6 & 5 & 60 & 9.0 & 100 & 60 \\
\hline P. rubens Biourge & 0 & 0 & 0 & 0 & 0 & 0 & $\mathbf{0}$ & 0.0 & 0.0 & 15 & 20 & 13 & 09 & 14 & 10 & 81 & 12.1 & 100 & 81 \\
\hline P. sanshaense & 0 & 0 & 0 & 0 & 0 & 0 & $\mathbf{0}$ & 0.0 & 0.0 & 3 & 5 & 6 & 7 & 2 & 1 & 24 & 3.6 & 100 & 24 \\
\hline $\begin{array}{l}\text { P. wotroi Houbraken, } \\
\text { López-Quint., Frisvad } \\
\& \text { Samson }\end{array}$ & 22 & 17 & 13 & 12 & 10 & 09 & 83 & 12.3 & 100 & 17 & 25 & 23 & 22 & 22 & 22 & 131 & 19.6 & 100 & 214 \\
\hline Penicillium sp. 1 & 04 & 03 & 03 & 03 & 10 & 09 & 32 & 4.7 & 100 & 0 & 0 & 0 & 0 & 0 & 0 & $\mathbf{0}$ & 0.0 & 0.0 & 32 \\
\hline Penicillium sp. 2 & 04 & 07 & 09 & 10 & 13 & 10 & 53 & 7.9 & 100 & 09 & 10 & 13 & 07 & 08 & 07 & 54 & 8.1 & 100 & 107 \\
\hline Penicillium sp. 3 & 10 & 9 & 8 & 7 & 8 & 7 & 49 & 7.3 & 100 & 0 & 0 & 0 & 0 & 0 & 0 & $\mathbf{0}$ & 0.0 & 0.0 & 49 \\
\hline Penicillium sp. 4 & 4 & 3 & 0 & 0 & 0 & 0 & 7 & 1.0 & 33.3 & 10 & 13 & 15 & 12 & 12 & 13 & 75 & 11.2 & 100 & 82 \\
\hline Penicillium sp.5 & 0 & 0 & 0 & 0 & 0 & 0 & $\mathbf{0}$ & 0.0 & 0.0 & 14 & 13 & 15 & 13 & 14 & 12 & 81 & 12.1 & 100 & 81 \\
\hline Penicillium sp. 6 & 10 & 10 & 18 & 17 & 09 & 09 & 73 & 10.8 & 100 & 0 & 0 & 0 & 0 & 0 & 0 & $\mathbf{0}$ & 0.0 & 0.0 & 73 \\
\hline $\begin{array}{l}\text { Talaromyces muroii } \\
\text { Yaguchi, Someya } \\
\text { \& Udagawa }\end{array}$ & 13 & 13 & 14 & 15 & 16 & 17 & 88 & 13.1 & 100 & 0 & 0 & 0 & 0 & 0 & 0 & $\mathbf{0}$ & 0.0 & 0.0 & 88 \\
\hline $\begin{array}{l}\text { T. verruculosus (Peyronel) } \\
\text { Samson, N. Yilmaz, } \\
\text { Frisvad \& Seifert }\end{array}$ & 0 & 0 & 0 & 0 & 0 & 0 & $\mathbf{0}$ & 0.0 & 0.0 & 12 & 13 & 12 & 12 & 13 & 14 & 76 & 11.3 & 100 & 76 \\
\hline Talaromyces sp. 1 & 13 & 12 & 11 & 12 & 12 & 12 & 72 & 10.7 & 100 & 0 & 0 & 0 & 0 & 0 & 0 & $\mathbf{0}$ & 0.0 & 0.0 & 72 \\
\hline $\begin{array}{l}\text { Total of species: } 16 \\
(\text { Penicillium }=13 ; \\
\text { Talaromyces }=03)\end{array}$ & 113 & 103 & 109 & 123 & 115 & 111 & 674 & 100 & - & 108 & 134 & 133 & 103 & 96 & 96 & 670 & 100 & - & 1.344 \\
\hline
\end{tabular}

Note. $(\mathrm{C} 1)=$ collection $1 ;(\mathrm{C} 2)=$ collection $2 ;(\mathrm{C} 3)=$ collection $3 ;(\mathrm{T})=$ total of isolates; $(\mathrm{RD} \%)=$ relative dominance percentage; $(\mathrm{RF} \%)=$ relative frequence percentage. 


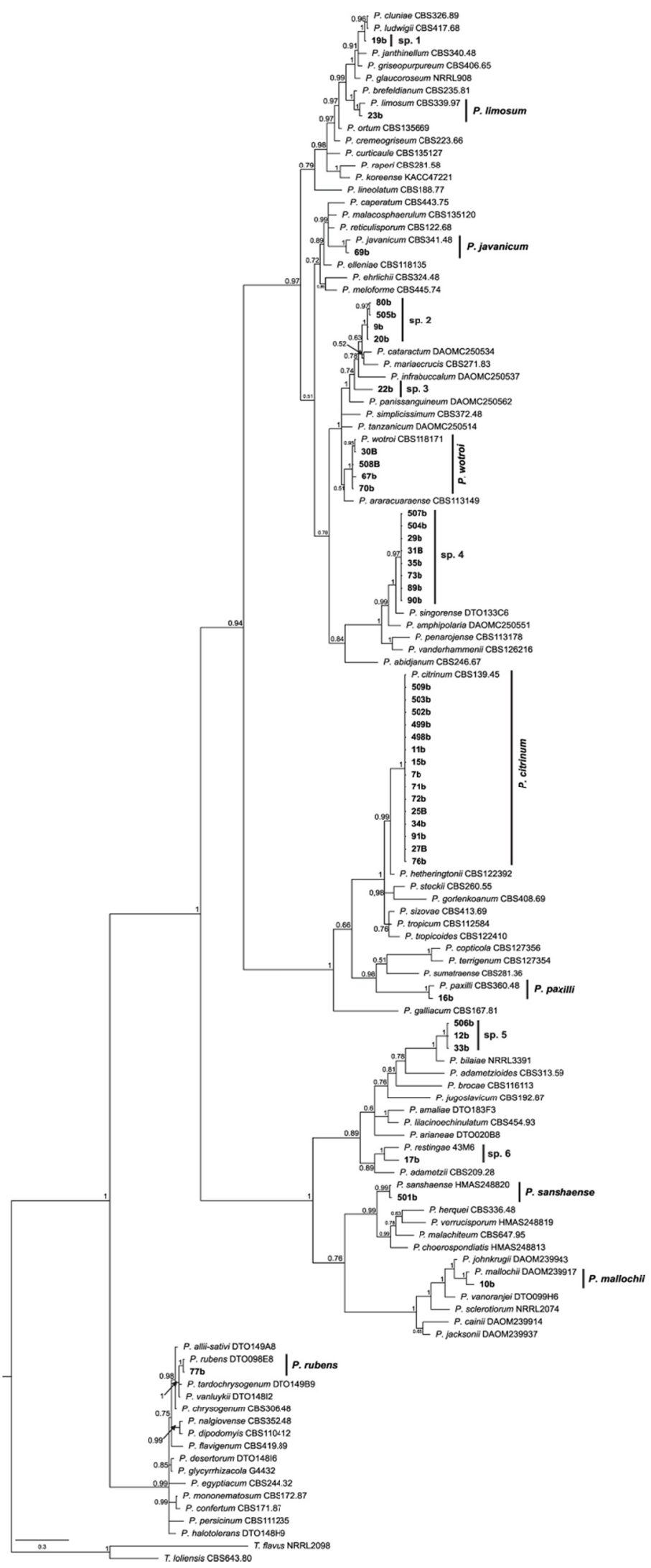

Figure 1. Phylogenetic tree of Penicillium species inferred from Bayesian analysis based on the $\beta$-tubulin sequences. Bayesian posterior probabilities are indicated above the nodes. The tree was rooted to Talaromyces flavus NRRL2098 and Talaromyces loliensis CBS643.80. The species obtained in this study are highlighted in bold 


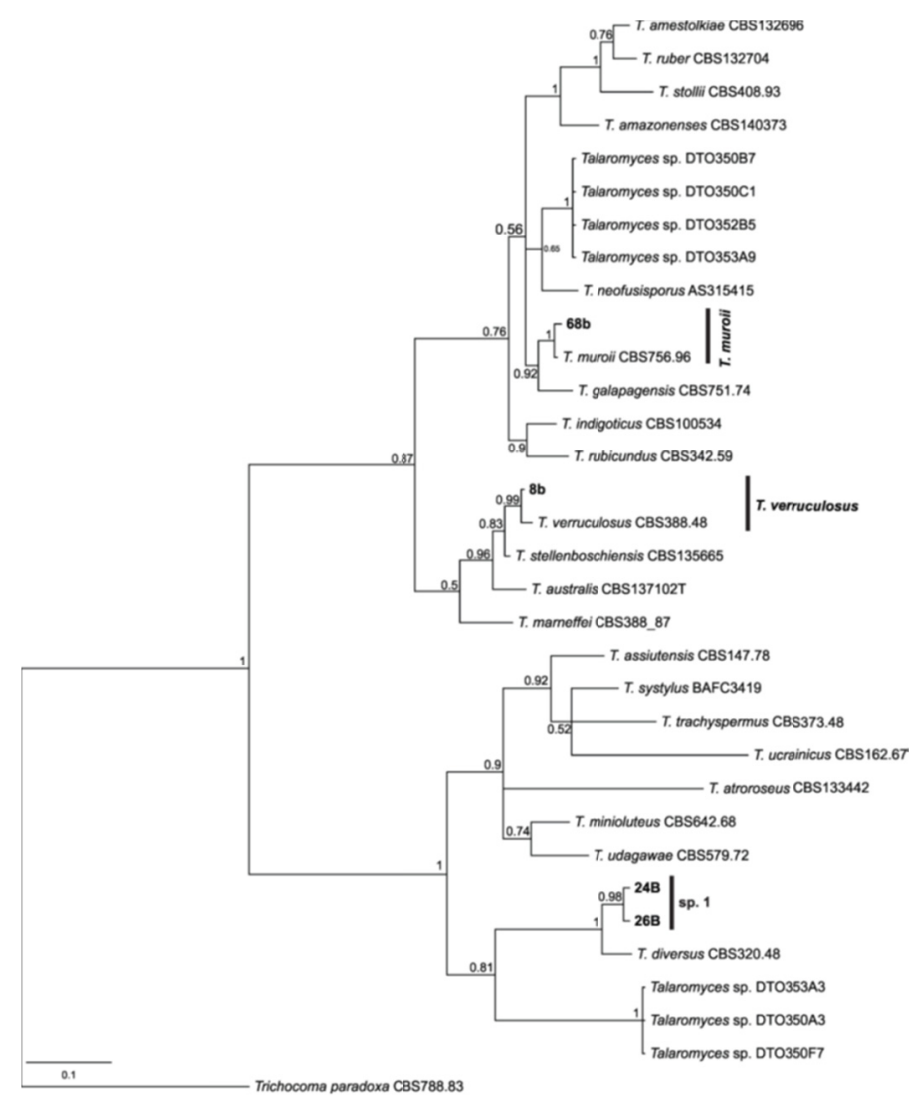

Figure 2. Phylogenetic tree of Talaromyces species inferred from Bayesian analysis based on the $\beta$-tubulin sequences. Bayesian posterior probabilities are indicated above the nodes. The tree was rooted to Trichocoma paradoxa CBS788.83. The species obtained in this study are highlighted in bold

\subsection{Ecological Analyses}

The rates of species diversity and equitability were similarly high in the two areas analyzed, with a slight increase occurring in the cultivated area (Figure 3). Samples from the cultivated area presented higher species richness (Figure 4). The fallow area presented higher abundance during the first two collections (Figure 5). Based on the relative dominance index, the dominant species in the cultivated area were Penicillium limosum, $P$. wotroi, Penicillium sp. 6, Talaromyces muroii, and Talaromyces sp.1. In the fallow area, six species dominated: Penicillium citrinum, P. rubens, P. wotroi, Talaromyces sp. 4, Talaromyces sp. 5 and Talaromyes verruculosus (Table 2). Penicilium wotroi was dominant in the two areas evaluated, besides presenting a $100 \%$ frequency of occurrence in both areas (Table 2, Figure 6). All the species found presented a frequency equal to or greater than $50 \%$, being considered constant (Figure 6). Regarding the species similarity analysis, the Copernican analysis yielded $\mathrm{r}=0.84$, indicating the presence of distinct groups. There were two major groups, each subdivided into two subgroups (Figure 7). The similarity analysis of the samples yielded $r=0.73$, showing well-adjusted data. Two groups were recorded: group 1 characterized the cultivated area (Culti) while Group 2 comprised the remaining samples (Figure 8). 


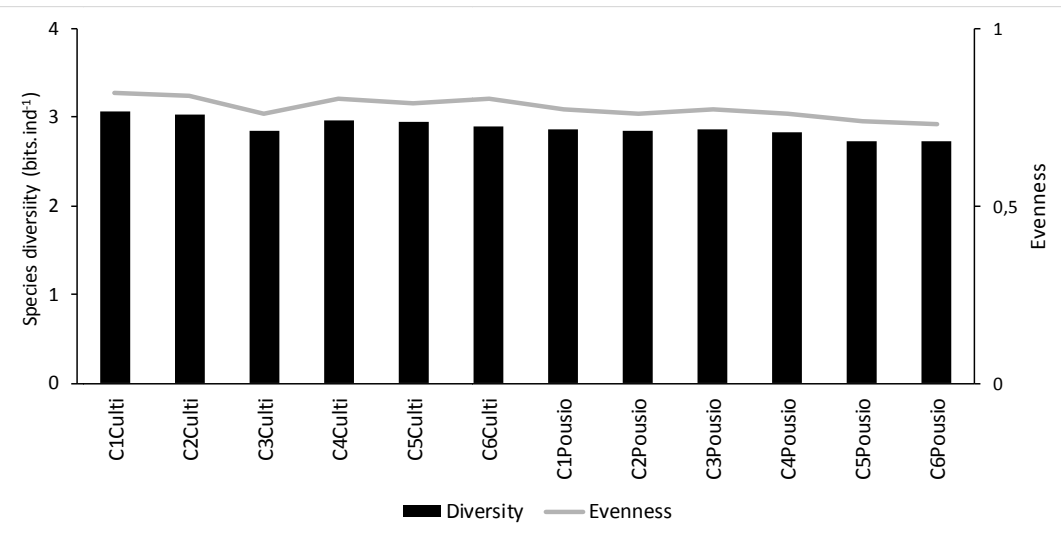

Figure 3. Diversity (bits.ind-1) and Pielou equitability of Penicillium and Talaromyces species of soils cultivated with sugarcane (Culti) and fallow (Pousio), in six collections (C1, C2, C3 C4, C5 and C6). Statistical analysis based on the Shannon and Pielou indices

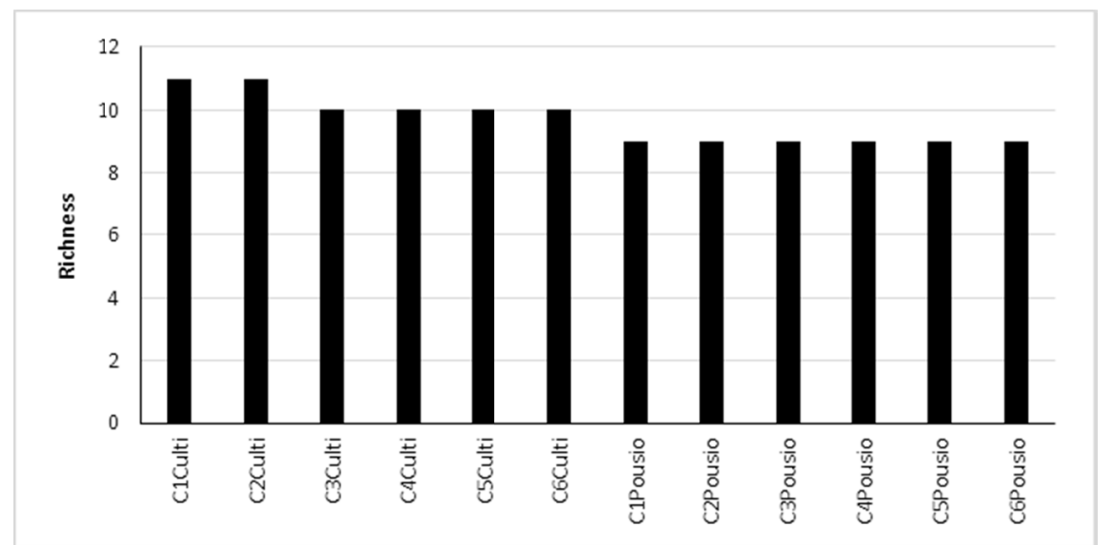

Figure 4. Wealth of Penicillium and Talaromyces species of soils cultivated with sugarcane (Culti) and fallow (Pousio), in six collections (C1, C2, C3, C4, C5 and C6)

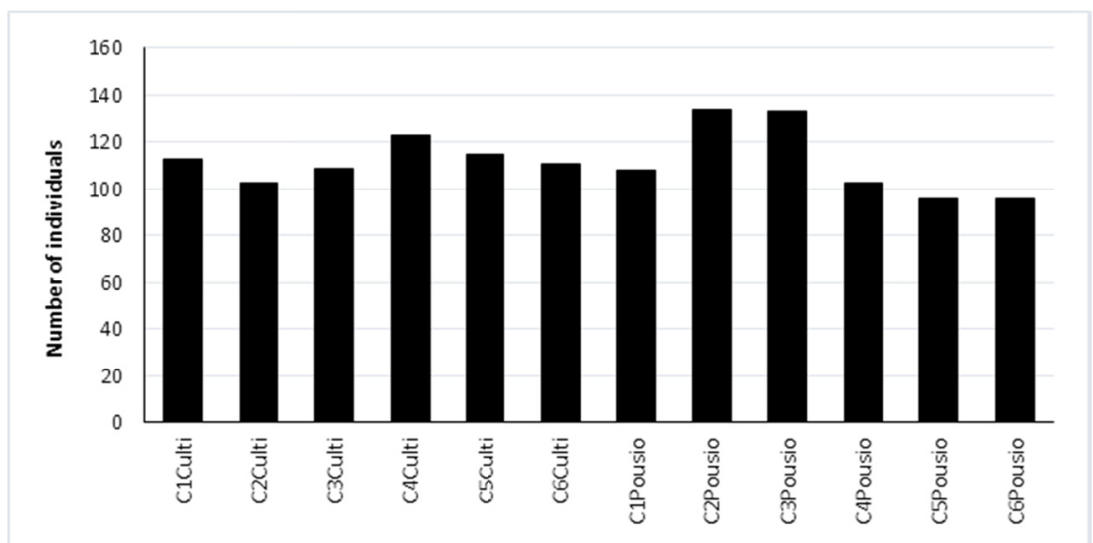

Figure 5. Abundance of Penicillium and Talaromyces of soils cultivated with sugarcane (Culti) and fallow (Pousio), in six collections (C1, C2, C3, C4, C5 and C6) 


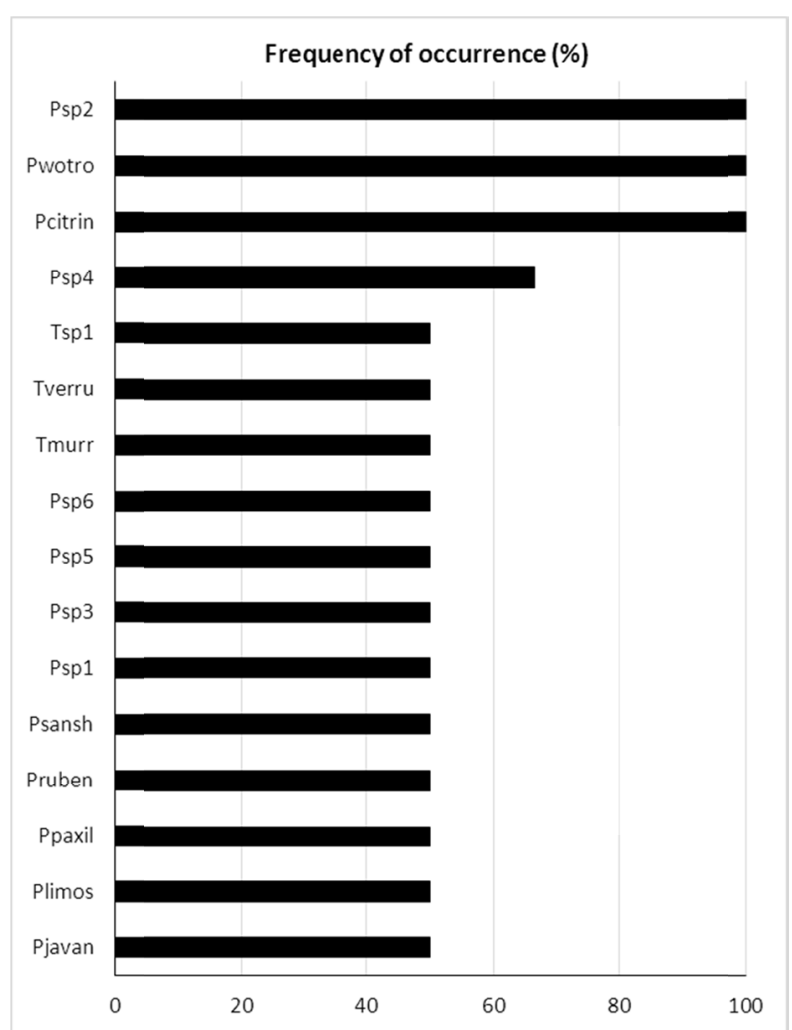

Figure 6. Frequency of occurrence of Penicillium and Talaromyces species from soils cultivated with sugarcane and fallow in six collections $(\mathrm{C} 1, \mathrm{C} 2, \mathrm{C} 3, \mathrm{C} 4, \mathrm{C} 5$ and $\mathrm{C} 6)$

Note $.($ Psp2 $)=$ Penicillium sp. $2 ;($ Pwotr $)=$ P. Wotroi $;($ Pcitrin $)=$ P. citrinum $;($ Psp4 $)=$ Penicillium sp $4 ;($ Tsp 1$)=$ Talaromyces sp. $1 ;($ Tverr $)=$ Talaromyces verruculosus $;($ Tmurr $)=$ T. murroi $;(\mathrm{Psp} 6)=$ Penicillium sp $6 ;=($ Psp5 $)$ $=$ Penicillium sp 5; $($ Psp3) = Penicillium sp 3; $($ Psp1 $)=$ Penicillium sp 1; $($ Psansh $)=$ P. sanshaense $;($ Pruben $)=P$. rubens $;($ Ppaxil $)=$ P. paxilli $;($ Plimos $)=P$. limosum $;($ Pjavan $)=P$. javanicum .

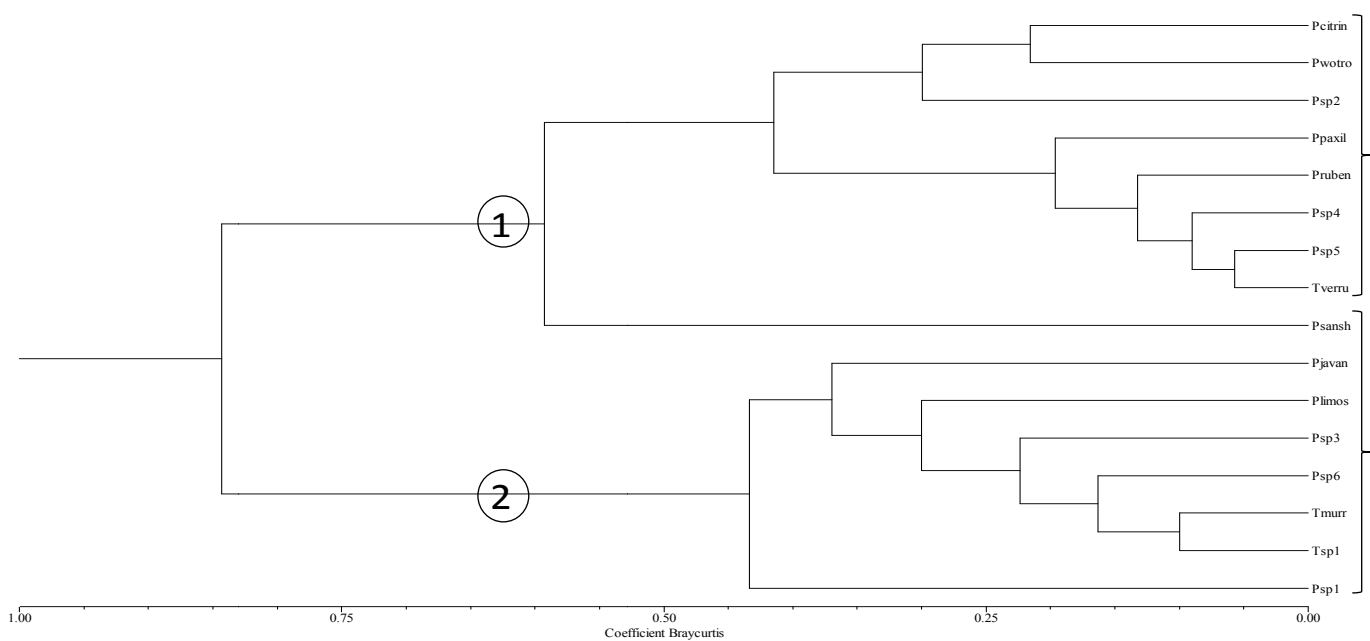

Figure 7. Proximal dendrogram between Penicillium and Talaromyces species from sugarcane soils from a mill located in the municipality of Sirinhaém, Pernambuco, Brazil. Statistical analysis based on the Bray-Curtis index; proportional weight binding method (WPGM, Weighted Pair-Group Method, Arithimetic Average). Coperetic analysis: $\mathrm{r} 0.84$

Note $($ Pcitrin $)=$ P. citrinum $($ Pwotr $)=$ P. Wotroi $;($ Psp2 $)=$ Penicillium sp. $2 ;($ Ppaxil $)=$ P. paxilli $($ Pruben $)=P$. rubens; $($ Psp4 $)=$ Penicillium sp 4; $($ Psp5 $)=$ Penicillium sp 5; $($ Tverr $)=$ Talaromyces verruculosus $;(\operatorname{Psansh})=P$. sanshaense $($ Pjavan $)=$ P. javanicum $;($ Plimos $)=$ P. limosum $;(\operatorname{Psp} 3)=$ Penicillium $\mathrm{sp} 3 ;(\mathrm{Psp} 6)=$ Penicillium $\mathrm{sp}$ $6 ;($ Tmurr $)=$ T. murroi $;($ Tsp 1$)=$ Talaromyces $\mathrm{sp} .1 ;=($ Psp1 $)=$ Penicillium sp 1. 


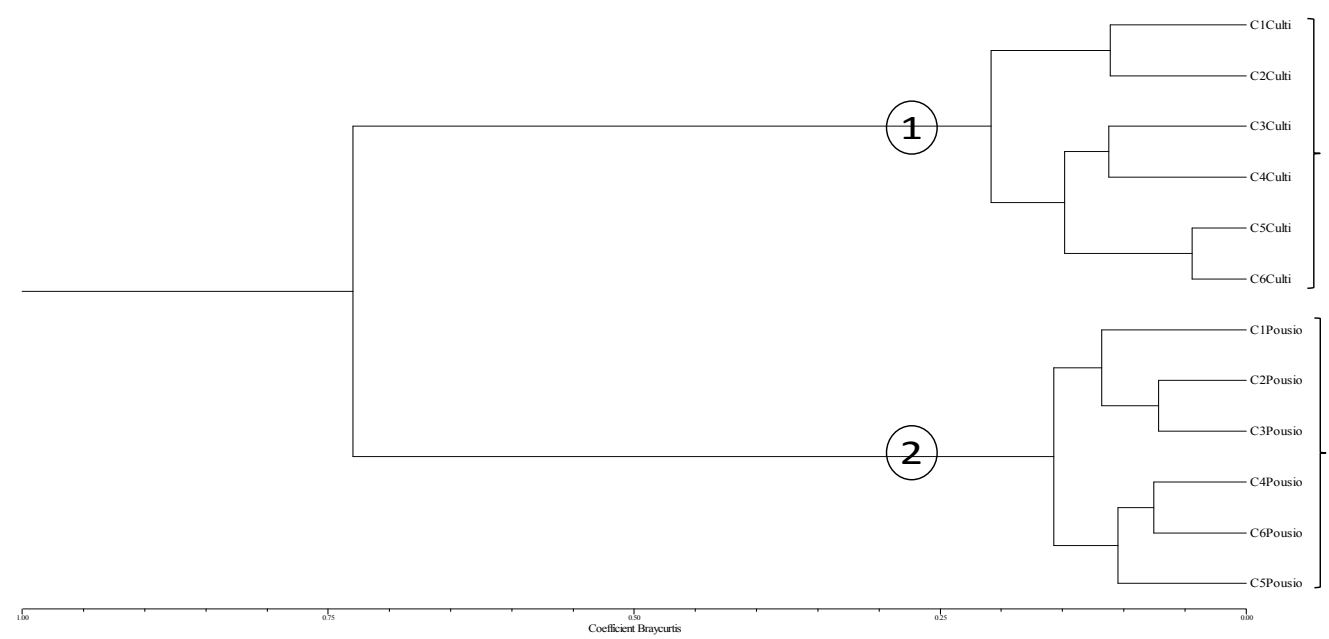

Figure 8. Dendrogram of proximity between the samples (six collections: C1, C2, C3, C4, C5 and C6) from soils cultivated with sugarcane and fallow area of a plant located in the municipality of Sirinhaém, Pernambuco, Brazil. Statistical analysis based on the Bray-Curtis index; proportional weight binding method (WPGM, Weighted Pair-Group Method, Arithimetic Average). Coperetic analysis: r 0.73

The result of PCA was significant, with the first three components accounting for $78.97 \%$ of the data variation. Component 1 accounted for $61.46 \%$, component 2 explained $9.09 \%$, and component $3,8.42 \%$ (Table 3 ).

The two-dimensional projection showed two groups: the fallow (Pousio) area group (right side) and the group associated with the cultivated area (left side). The Pousio group associated Pencillium citrinum, P. paxilli, P. rubens, P. sanshaense, P. wotroi, Penicillium sp. 4, Penicillium sp. 5, and T. verruculosus with temperature, carbon content, $\mathrm{pH}$, and $\mathrm{P}$ content. The cultivated area group associated Penicillium javanicum; P. limosum; Penicillium spp. 1, 3, and 6; Talaromyces murroi; and Talaromyces sp. 1 with the contents of $\mathrm{Al}, \mathrm{Na}, \mathrm{K}, \mathrm{Ca}, \mathrm{Mg}$, and H. In the fallow (Pousio) area group, the species Talaromyces verruculosus and Penicillium sp. 5, were influenced by $\mathrm{pH}$. In the cultivated area group, Talaromyces sp. 1 was important, with $\mathrm{Al}$ and $\mathrm{Mg}$ being the most influential factors (Figure 9, Table 3). 
Table 3. Analysis of the first 3 main components

\begin{tabular}{|c|c|c|c|}
\hline Species and parameters & $\begin{array}{l}\text { Component } 1 \\
(61.46 \%)\end{array}$ & $\begin{array}{l}\text { Component } 2 \\
(9.09 \%)\end{array}$ & $\begin{array}{l}\text { Component } 3 \\
(8.42 \%)\end{array}$ \\
\hline Penicillium citrinum & 0.6412 & 0.4369 & 0.4922 \\
\hline P. javanicum & -0.7539 & 0.4364 & -0.1527 \\
\hline P. limosum & -0.9548 & -0.1929 & 0.1657 \\
\hline P. paxilli & 0.8728 & 0.1883 & 0.4276 \\
\hline P. rubens & 0.9467 & 0.0646 & 0.1659 \\
\hline P. sanshaense & 0.8225 & 0.1970 & 0.1667 \\
\hline P. wotroi & 0.7829 & 0.2276 & -0.2552 \\
\hline Penicillium sp 1 & -0.8050 & -0.1197 & 0.2124 \\
\hline Penicillium sp 2 & 0.0438 & -0.2257 & 0.7927 \\
\hline Penicillium sp 3 & -0.9732 & 0.0810 & -0.0422 \\
\hline Penicillium sp 4 & 0.9749 & 0.0587 & -0.0610 \\
\hline Penicillium sp 5 & 0.9942 & 0.0113 & 0.0112 \\
\hline Penicillium sp 6 & -0.9032 & -0.0802 & 0.0386 \\
\hline Taloromyces murroi & -0.9908 & -0.0385 & 0.0805 \\
\hline T. verruculosus & 0.9898 & -0.0463 & -0.0495 \\
\hline Talaromyces sp 1 & -0.9929 & 0.0568 & 0.0046 \\
\hline Temperature & 0.7185 & -0.4784 & -0.3211 \\
\hline $\mathrm{pH}$ & 0.9298 & 0.2989 & -0.0184 \\
\hline $\mathrm{P}$ & 0.3414 & 0.1282 & -0.2889 \\
\hline $\mathrm{Al}$ & -0.9330 & -0.1918 & -0.0011 \\
\hline $\mathrm{Na}$ & -0.7871 & 0.2935 & -0.1585 \\
\hline $\mathrm{K}$ & -0.2515 & 0.3750 & 0.7769 \\
\hline $\mathrm{Ca}$ & -0.3359 & -0.0583 & 0.2826 \\
\hline $\mathrm{Mg}$ & -0.9055 & 0.0782 & 0.0060 \\
\hline $\mathrm{H}$ & -0.4592 & 0.2304 & 0.0287 \\
\hline Organic Matterr & 0.1577 & -0.8377 & 0.2809 \\
\hline Carbon & 0.4862 & -0.6742 & 0.1170 \\
\hline
\end{tabular}

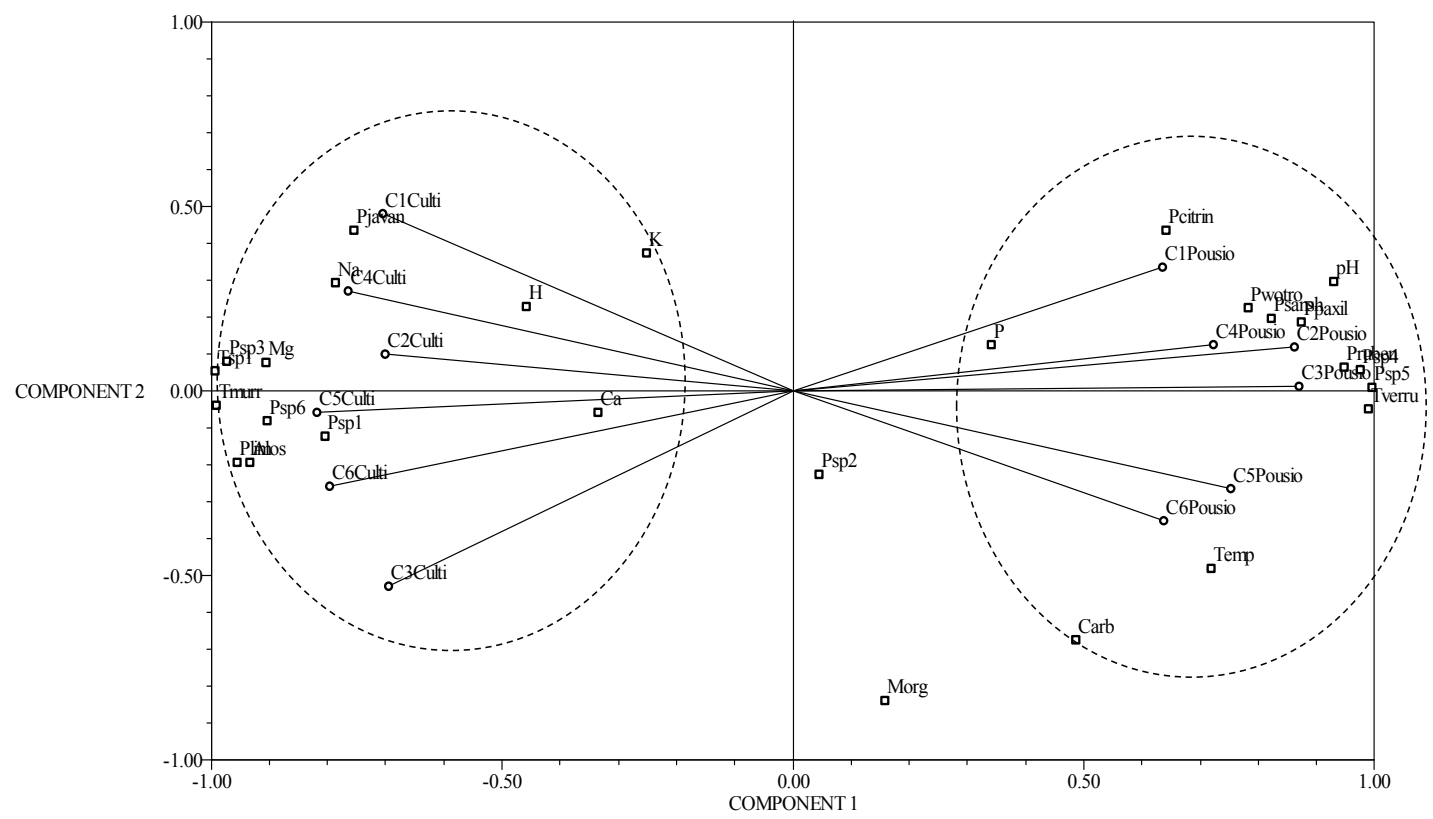

Figure 9. Two-dimensional projection of the first two factors of the Principal Component Analysis of samples of soils of cultivated area with sugar cane (Culti) and fallow (Pousio), in six collections (C1, C2, C3, C4, C5 and C6) from a mill located in the municipality of Sirinhaém, Pernambuco, Brazil. Factor 1 (Dinn-1) and Factor 2 (Dinn-2) 


\section{Discussion}

Among the natural resources fundamental to the functioning of terrestrial ecosystems, the soil is outstanding (Lourente et al., 2011). According to Melloni et al. (2008), the soil represents a balance between physical, chemical, and biological factors, whose biological fraction is mainly composed of microorganisms. In this context, we highlight filamentous fungi belonging to the genus Penicillium and Talaromyces. These fungi play a prominent role in the soil, as they are excellent decomposers of organic matter (Schimel et al., 2007; Taniwaki et al., 2015). Despite their great importance in maintaining the biosphere, it is believed that many species of these genera have not yet been discovered or described (Pitt, 1991).

In the present study, high diversity of Penicillium and Talaromyces was observed in the soil samples in both cultivated and fallow areas. The theory of time, elaborated by Simpson (1964), affirms that communities tend to diversify with time. According to the author, older communities are more diverse than younger ones. Based on this theory, it is possible to justify the high diversity of Penicillium and Talaromyces found in the soils of the evaluated areas, since there is no crop rotation, with only sugarcane being planted, since 1887 . The hypothesis of Menge and Sutherland (1976) corroborates the theory of time by asserting that communities with high diversity emerge from environments that are stable for long periods of time. However, extends this concept by asserting that the elevation of diversity is the result of a diversification of niches, maintained by competition (specialization). In short, a high diversity is attributed to intense competition, which induces the expansion of niches. For both areas (cultivated and fallow), the Pielou equitability index was high, indicating that the populations of the two evaluated communities were well distributed among the analyzed samples, and there was no imbalance. However, in both communities, there are dominant species, especially Penicillium wotroi, which dominated in both areas. The dominance of $P$. wotroi indicates good species adaptation to the soils of sugarcane cultivation. According to Alves et al. (2011), the biological soil fraction is dynamic and easily affected by agricultural management. This fact can be verified for the analyzed areas by applying the Bray-Curtis distance (Magurram, 1988), used to graphically visualize the proximity between the two analyzed communities. When we applied this distance measure to samples by collection, we observed the formation of two large groups (cultivated area and fallow area), indicating the individuality of each community. This can be observed in the dendrogram shown in Figure 8. When the same analysis was applied to species, one could also observe the formation of two large groups (cultivated area and fallow area) and within each one, the formation of two subgroups. Such groupings may indicate that the species that group together have similar ecological niches in the community and are therefore closely related (Figure 7). These species probably present similar nutritional standards.

According to the ACP, in the community fallow area, the main factors that have a direct influence on some populations are temperature, $\mathrm{pH}$, and carbon and phosphorus levels, that is, an increase in these factors contributes to the growth of the populations they influence. However, the populations of Talaromyces verruculosum and Penicillium sp. 5 were even more sensitive to $\mathrm{pH}$. For the cultivated area community, other factors influenced the population dynamics. The levels of $\mathrm{Al}, \mathrm{Na}$, and $\mathrm{Mg}$ showed greater influences on some populations. However, the analysis highlighted the population of Talaromyces sp. 1 under strong influence of Al and $\mathrm{Mg}$ contents.

In the last 10 years, species of the genus Penicillium have been reported as endophytic of sugarcane, as well as isolated from the rhizosphere of this culture (Stuart, 2006; Mendes, 2008; Fávaro, 2009). Souza-Motta et al. (2003) evaluated the diversity of fungi present in the sunflower rhizosphere (Helianthus annus L.), cultivated in the Atlantic Forest area, and prospected and identified 49 species of filamentous fungi. Among the genera found, Penicillium was the most representative, with nine species: P. citreonigrum, P. fellutanum, $P$. janthinellum, $P$. oxalicum, P. restrictum, $P$. variabile, $P$. verruculosum, $P$. vinaceum, and $P$. waksmanii. According to the authors, the genus Penicillium is the most frequent in the sunflower rhizosphere (Helianthus annus L.) of the analyzed area. When isolating rhizosphere fungi from melon trees (Cucumis melo L. cv. Gold Mine) cultivated in soils rich in organic compounds, Coutinho et al. (2010) identified 78 species, the most abundant genera being Aspergillus and Penicillium, with 15 and 13 species, respectively. P. citrinum, P. corylophilum, P. decumbens, $P$. dierckxii, P. griseofulvum, P. janthinellum, P. pinophilum, P. waksmanii, P. restrictum, P. solitum, P. spinulosum, and $P$. vinaceum were identified. There was no similarity between the species found in the present study and those found in Souza-Motta et al. (2003) and Coutinho et al. (2010), suggesting that the sugar cane can select the community of filamentous fungi present in the soil. In 2007, Gomez et al. evaluated the diversity of fungi present in Argentine soils impacted by deforestation of native vegetation for different management. The authors found greater representation of isolates belonging to the genera Penicillium and Aspergillus and suggested that this result was related to the antagonism toward phytopathogenic species and their low nutritional requirement. In 
2010, Fraga et al. evaluated the diversity of species of the Trichocomaceae family present in soils of two forest systems (Pinus and Corymbia) in Brazil. The authors obtained 190 isolates, distributed in 54 species. Penicillium was the most representative genus with 32 species, both for the area planted with individuals of the Pinus genus and for the Corymbia area. Penicillium decumbens was the most abundant fungus species, identified in all samples at different temperature and humidity conditions, independent of the vegetation cover (Fraga et al., 2010a). Also in 2010, Fraga et al. evaluated the soil fungal community of a dune located in Brazil. The most frequent genera were Penicillium, Aspergillus, and Trichoderma. From the genus Penicillium, $P$. arenicola, $P$. corylophilum, P. decumbens, P. echinulatum, P. javanicum, P. miczynskii, P. paxilli, P. purpurogenum, P. sclerotiorum, and $P$. simplicissimum were identified. According to the authors, two species belonging to this genus could not be identified based on morphology (Fraga et al., 2010b). In the present study, in contrast to the work of Fraga et al. (2010b), only Penicillium javanicum and P. paxilli were isolated from sugarcane-cultivated soils.

Fraga and Pereira (2012) evaluated the diversity as well as the succession of Trichocomaceae in areas of Atlantic Forest with different levels of anthropization, located in the Natural Park in the State of Rio de Janeiro, Brazil. The areas were classified by the authors as the most impacted area and the least impacted area. A total of 87 fungi samples were isolated, distributed into four genera and 22 species. From the genus Penicillium, 16 species were identified, this being the most representative genus in the two studied areas. In the present study, the same number of species was found, but six were new discoveries.

In 2013, Cruz et al. evaluated the community of Penicillium present in Atlantic Forest remnant soils located in the capital of Pernambuco, Brazil during the rainy and dry seasons. The authors obtained 445 isolates, distributed into 17 species (Cruz et al., 2013). In the present work on sugarcane-cultivated soils, although we found lower species richness (16 species), new species of Penicillium and Talaromyces were found, a fact that proves the relevance of studies of microbial diversity in under- or unstudied environments, such as sugarcane soils.

Based on the present study, it can be concluded that sugarcane-cultivated soils represent excellent sources of Penicillium and Talaromyces and harbor rare species and/or those not yet described by taxonomists. Such fallow soils present distinct communities although they present some common species.

\section{Acknowledgements}

The authors are grateful for the technical and financial support offered by the Graduate Program in Fungi Biology of UFPE, as well as Dr. Sigrid Newman (UFPE) for all the support in the statistical analyzes carried out.

\section{References}

Alves, T. S., Campos, L. L., Elias, Neto N., Matsuoka, M., \& Loureiro, M. F. (2011). Biomassa e atividade microbiana de solo sob vegetação nativa e diferentes sistemas de manejos. Acta Scientiarum Agronomy, 33(2), 341-347. https://doi.org/10.4025/actasciagron.v33i2.4841

Araújo, A. S. F., \& Monteiro, R. T. R. (2007). Biological indicators of soil quality. Bioscience Journal, 23(3), 66-75.

Barros, R. P., Viégas, P. R. A., Silva, T. L., Souza, R. M., Barbosa, L., Viégas, R. A., .. Melo, A. S. (2010). Alterações em atributos químicos de solo cultivado com cana-de-açúcar e adição de vinhaça. Pesquisa Agropecuária Tropical, 40(3), 341-346. https://doi.org/10.5216/pat.v40i3.6422

Blackithi, R. E., \& Reyment, R. A. (1971). Multivariate Morphometrics. London, Academic Press.

Blackwell, M. (2011). The Fungi: 1, 2, 3 .. 5, 1 milion species? American Journal of Botany, 98, 426-238. https://doi.org/10.3732/ajb.1000298

Camilotti, F., Andrioli, I., Marques, M. O., Silva, A. R., Tasso Júnior, L. C., \& Nobile, F. O. (2006). Atributos físicos de um latossolo cultivado com cana-de-açúcar após aplicações de lodo de esgoto e vinhaça. Engenharia Agricola, 26(3), 738-747. https://doi.org/10.1590/S0100-69162006000300010

Canellas, L. P., Velloso, A. C. X., Marciano, C. R., Ramalho, J. F. G. P., Rumjanek, V. M., Rezende, C. E., \& Santos, G. A. (2003). Propriedades químicas de um cambissolo cultivado com cana-de-açúcar, com preservação do palhiço e adição de vinhaça por longo tempo. Revista Brasileira de Ciências do Solo, 27(5), 935-944. https://doi.org/10.1590/S0100-06832003000500018

Clark, F. E. (1965). Ágar-plate method for total microbial count. In C. A. Black, D. D. Evans, J. L. White, L. E. Ensminger, F. E. Clark, \& R. C. Dinaver (Eds.), Methods of soil analysis, Part 2. Chemical and microbiological properties (pp. 1460-1466). Madson Inc, New York. 
CONAB (Companhia Nacional de Abastecimento). (2017). Séries Históricas de Área Plantada, Produtividade e Produção, Relativas às Safras 1976/77 a 2015/16 de Grãos, 2001 a 2016 de Café, 2005/06 a 2016/17 de Cana-de-Açúcar. Retrieved September 30, 2009, from http://www.conab.gov.br/conteudos.php?a=1252et= ePagina_objcmsconteudos=2\#A_objcmsconteudos

Coutinho, F. P., Cavalcanti, M. A. Q., \& Yano-Melo, A. M. (2010). Filamentous fungi isolated from the rhizosphere of melon plants (Cucumis melo L. cv. Gold Mine) cultivated in soil with organic amendments. Botânica Brasílica, 24(1), 292-298. https://doi.org/10.1590/S0102-33062010000100032

Cruz, R., Santos, C., Lima, J. S., Moreira, K. A., \& Souza-Motta, C. M. (2013). Diversity of Penicillium in soil of Caatinga and Atlantic Forest areas of Pernambuco, Brazil: an ecological approach. Nova Hedwigia, 97, 543-556. https://doi.org/10.1127/0029-5035/2013/0127

Embrapa (Empresa Brasileira de Pesquisa Agropecuária). (2009). Manual de Análises Químicas de Solos Plantas e Fertilizantes (2nd ed.). Brasília, DF: Embrapa Informação Tecnológica.

Fávaro, L. C. L. (2009). Diversidade e interação de Epicoccum spp. com cana-de-açúcar (Saccharum officinarum L.) [Tese (Doutorado em Genética e Melhoramento de Plantas), Escola Superior de Agricultura "Luiz de Queiroz", Universidade de São Paulo, Piracicaba, São Paulo].

Fraga, M. E., \& Pereira, M. G. (2012). Diversidade de Trichocomaceae Isolada de Solo e Serrapilheira de Floresta Atlântica. Floresta e Ambiente, 19(4), 405-413. https://doi.org/10.4322/floram.2012.045

Fraga, M. E., Pereira, M. G., \& Souza, F. A. (2010b). Micobiota do Solo de uma Área de Duna na Restinga da Marambaia, Rio de Janeiro, RJ. Floresta e Ambiente, 17(1), 1-7. https://doi.org/10.4322/floram.2011.007

Fraga, M. E., Pereira, M. G., Barbosa, D. J., \& Melo, M. P. (2010a). Diversity of isolated Trichocomaceae from soil in two forest ecosystems. Ciência Florestal, 20(1), 167-175.

Glass, N. L., \& Donaldson, G. C. (1995). Development of premier sets designed for use with the PCR to amplify conserved genes from filamentous Ascomycetes. Applied and Environmental Microbiology, 61(4), 1323-1330.

Glória, N. A., \& Orlando Filho, J. (1983). Aplicação de vinhaça como fertilizante. São Paulo, Coopersucar.

Gomez, E. R., Pioli, R., \& Conti, M. (2007). Fungal abundance and distribution as influenced by clearing and land use in a vertic soil of Argentina. Biology and Fertilily Soils, 43, 373-377. https://doi.org/ 10.1007/s00374-006-0112-7

Gucinski, H., Vance, E., \& Reiners, W. A. (1995). Potential effects of global climate change. In W. K. Smith, \& T. M. Hinckley (Eds.), Ecophysiology of Coniferous Forests. San Diego, Academic Press. https://doi.org/ 10.1016/B978-0-08-092593-6.50015-3

Hall, T. (2014). BioEdit v7.0.9: Biological sequence alignment editor for Win95/98/2K/XP/7. Retrieved July 13, 2014, from http://www.mbio.ncsu.edu/bioedit.html

Higgins, D., Thompson, J., Gibson, T., Thompson, J. D., Higgins, D. G., \& Gibson, T. J. (1994). CLUSTAL W: improving the sensitivity of progressive multiple sequence alignment through sequence weighting, position-specific gap penalties and weight matrix choice. Nucleic Acids Research, 22, 4673-4680. https://doi.org/10.1093/nar/22.22.4673

Houbraken, J., \& Samson, R. A. (2011). Phylogeny of Penicillium and the segregation of Trichocomaceae into three families. Studies in Mycology, 70, 1-51. https://doi.org/10.3114/sim.2011.70.01

Koffler, N. F., Lima, J. F. W. F., De Lacerda, M. F., Santana, J. F., \& Silva, M. A. (1986). Caracterização Edafo-climática das Regiões Canavieiras do Brasil: Pernambuco. IAA/PLANALSUCAR, Piracicaba.

Kumar, S., Stecher, G., \& Tamura, K. (2015). MEGA7: Molecular Evolutionary Genetics Analysis Version 7.0. Molecular Biology and Evolution. Retrieved from http://www.megasoftware.net

Lourente, E. R. P., Mercante, F. M., Alovisi, A. M. T., Gomes, C. F., Gasparini, A. S., \& Nunes, C. M. (2011). Atributos microbiológicos, químicos e físicos de solo sob diferentes sistemas de manejo e condições de Cerrado. Pesquisa Agropecuária Tropical, 41(1), 20-28.

Magurran, M. E. (1988). Ecological diversity and its measurement. Princeton, University Press. https://doi.org/ 10.1007/978-94-015-7358-0 
Melloni, R., Melloni, E. G. P., Alvarenga, M. I. N., \& Vieira, F. B. M. (2008). Avaliação da qualidade de solos sob diferentes coberturas florestais e de pastagem no sul de minas gerais. Revista Brasileira de Ciências do Solo, 32, 2461-2470. https://doi.org/10.1590/S0100-06832008000600023

Mendes, R. (2008). Diversidade e caracterização genética de comunidades endofiticas associadas à cana-de-açúcar [Tese (Doutorado em Genética e Melhoramento de Plantas), Escola Superior de Agricultura "Luiz de Queiroz", Universidade de São Paulo, Piracicaba, São Paulo].

Menge, B. A., \& Sutherland, J. P. (1976). Species Diversity Gradients: Synthesis of the Roles of Predation, Competition, and Temporal Heterogeneity. The American Naturalist, 110(973), 351-369. https://doi.org/ $10.1086 / 283073$

Miller, M. A., Pfeiffer, W., \& Schwartz, T. (2010). Creating the CIPRES Science Gateway for inference of large phylogenetic trees. Proceedings of the Gateway Computing Environments Workshop (GCE) (pp. 1-8). New Orleans, LA. https://doi.org/10.1109/GCE.2010.5676129

Moraes, E. R., Domingues, L. A. S., Medeiros, M. H., Peixoto, J. V. M., \& Lana, R. M. Q. (2016). Produtividade e características agronômicas da cana-de-açúcar em diferentes sistemas de preparo do solo. Revista de Agricultura Neotropical, 3(1), 27-32.

Pereira, M. S., \& Alves, R. R. N. (2007). Composição Florística de um remanescente de Mata Atlântica na Área de Proteção Ambiental Barra do Rio Mamanguape, Paraíba, Brasil. Revista de Bologia e Ciências da Terra, 7(1), 1-10.

Pimentel, M. S., Oliveira, N. G., Costa, J. R., Almeida, D. L., \& De-Polli H. (2008). Atributos químicos e microbianos do solo sob diferentes manejos no município de Seropédica, RJ. Revista Brasileira Agrociência, 14(2), 307-317.

Pinto-Coelho, R. M. (2002). Fundamentos em Ecologia. São Paulo, Artmed.

Pitt, J. I. (1991). A laboratory Guide to Common Penicillium Species. North Wales, Commonwealth Scientific and Industrial Research Organization, Division of Food Processing.

Posada, D., \& Buckley, T. R. (2004). Model selection and model averaging in phylogenetics: Advantages of Akaike information criterion and Bayesian approaches over likelihood ratio tests. Systematic Biology, 53, 793-808. https://doi.org/10.1080/10635150490522304

Rambaut, A. (2009). Fig Tree 1.2.2. Retrieved April 20, 2017, from http http://tree.bio.ed.ac.uk/software/figtree

Rannala, B., \& Yang, Z. (1996). Probability distribution of molecular evolutionary trees: A new method of phylogenetic inference. Journal of Molecular Evolution, 43, 304-311. https://doi.org/10.1007/BF02338839

Raper, K. B., \& Thom, C. (1949). A manual of the Penicillia. Baltimore, USA, Williams and Wilkins.

Rohlf, F. J. (1993). NTSYS-PC: Numerical taxonomy and multivariate analysis system (Version 1.80). New York, Steauket: Applied Biostatistics.

Rohlf, F. J., \& Fisher, D. L. (1968). Test for hierarchical structure in random data sets. Systematic Zoology, 17, 407-412. https://doi.org/10.2307/2412038

Ronquist, F., \& Heulsenbeck, J. P. (2003). MrBayes 3: Bayesian phylogenetic inference under mixed models. Bioinformatics, 19, 1572-1574. https://doi.org/10.1093/bioinformatics/btg180

Saldanha, E. C. M., Rocha, A. T., Oliveira, E. C. A., Nascimento, C. W. A., \& Freire, F. J. (2007). Uso do gesso mineral em latosssolo cultivado com cana de açúcar. Caatinga, 20(1), 36-42.

Samson, R. A., Yilmaz, N., Houbraken, J., Spierenburg, H., Seifert, K. A., Peterson, S. W., ... Frisvad, J. C. (2011). Phylogeny and nomenclature of the genus Talaromyces and taxa accommodated in Penicillium subgenus Biverticillium. Studies in Mycology, 70, 159-183. https://doi.org/10.3114/sim.2011.70.04

Schimel, J., Balser, T. C., \& Wallenstein, M. (2007). Microbial stress-response physiology and its implications for ecosystem function. Ecology, 6(88), 1386-1394. https://doi.org/10.1890/06-0219

Silva, M. A. S., Griebeler, N. P., \& Borges, L. C. (2007). Uso de vinhaça e impactos nas propriedades do solo e lençol freático. Revista Brasileira de Engenharia Agrícola e Ambiental, 11(1), 108-114. https://doi.org/ 10.1590/S1415-43662007000100014

Simpson, G. G. (1964). Species density of North American recent mammals. Systematic Zoology, 13, 57-73. https://doi.org/10.2307/2411825 
Souza-Motta, C., Cavalcanti, M. A. Q., Fernandes, M. J. S., Lima, D. M. M., Nascimento, J. P., \& Laranjeira, D. (2003). Identification and Characterization of filamentous fungi isolated from sunflower (Helliantus annus L.) rhizosphere according to their capacity to hidrolyse inulin. Brazilian Journal of Microbiology, 34, 273-280. https://doi.org/10.1590/S1517-83822003000300018

Stuart, R. M. (2006). Comunidade de fungos endofiticos associada à cana-de-açúcar convencional e geneticamente modificada [Dissertação de mestrado (Mestrado em Microbiologia Agrícola), Escola Superior de Agricultura “Luiz de Queiroz”, Universidade de São Paulo, Piracicaba, São Paulo].

Taniwaki, M. H., Pitt, J. I., Iamanaka, B. T., Massi, F. P., Fungaro, M. H., \& Frisvad, J. C. (2015). Penicillium excelsum sp. nov from the Brazil Nut Tree Ecosystem in the Amazon Basin. PLoS One, 10(12), e0143189. https://doi.org/10.1371/journal.pone.0143189

Vasconcelos, R. F. B., Barros, C. J. R. B., Oliveira, V. S., Costa, Y. D. J., \& Cavalcante, D. M. (2010). Estabilidade de agregados de um latossolo amarelo distrocoeso de tabuleiro costeiro sob diferentes aportes de resíduos orgânicos da cana-de-açúcar. Revista Brasileira de Ciências do Solo, 34, 309-316. https://doi.org/10.1590/S0100-06832010000200004

Visagie, C. M., Houbraken, J., Frisvad, J. C., Hong, S. B., Klassen, C. H. W., Perrone, ... Samson, R. A. (2014). Identification and nomenclature of the genus Penicillium. Studies in Mycology, 78, 343-371. https://doi.org/ 10.1016/j.simyco.2014.09.001

Visagie, C. M., Seifert, K. A., Houbraken, J., Samson, R. A., \& Jacob, K. (2016). A phylogenetic revision of Penicillium sect. Exilicaulis, including nine new species from fynbos in South Africa. IMA Fungus, 7(1), 75-117. https://doi.org/10.5598/imafungus.2016.07.01.06

Wang, X., Chen, K., Zeng, Z., \& Zhuang, W. (2017). Phylogeny and morphological analyses of Penicillium section Sclerotiora (Fungi) lead to the discovery of five new species. Scientific Reports, 7(8233), 1-14. https://doi.org/10.1038/s41598-017-08697-1

\section{Copyrights}

Copyright for this article is retained by the author(s), with first publication rights granted to the journal.

This is an open-access article distributed under the terms and conditions of the Creative Commons Attribution license (http://creativecommons.org/licenses/by/4.0/). 